\title{
Effect of natural antioxidant treatment and modified atmosphere packaging on the quality and shelf-life of chilled beef
}

\author{
D.K. Balev ${ }^{1}$, A.S. Staykov ${ }^{3}$, G.Y. Ivanov ${ }^{2 *}$, S.G. Dragoev' ${ }^{1}$, E.H. Filizov ${ }^{1}$, K.P. Vassilev ${ }^{1}$ \\ and T.G. Grozdeva ${ }^{1}$
}

${ }^{1}$ Department of Meat and Fish Technology, and ${ }^{2}$ Department of Food Preservation and Refrigerated Technology, Technological Faculty, University of Food Technologies, 26 Maritza blvd., 4002 Plovdiv, Bulgaria

${ }^{3}$ Department of State Veterinary Supervision, Regional Veterinary Sanitary Service, 4400

Pazardjik, $4^{\mathrm{B}}$ Prof. Ivan Batakliev str., flow 1, flat 27, Bulgaria *Corresponding author: e-mail: ivanovgalin@yahoo.com, Phone: +359 32603800

\begin{abstract}
The possibility for quality improvement and shelf life extension of beef trimmings and beef knuckles by a combination of modified atmosphere packaging $\left(80 \% \mathrm{O}_{2} / 20 \% \mathrm{CO}_{2}\right)$ and superficial spraying with taxifolin solution $\left(1 \mathrm{~g} / \mathrm{dm}^{3}\right)$ was studied. This type of treatment reduced by $10-27 \%$ amino nitrogen content and by $7-12 \%$ acid value, of beef cuts stored at $0 \pm 0.5^{\circ} \mathrm{C}$. According to the microbiological tests the shelf-life of beef treated with taxifolin and packaged in modified atmosphere was extended with 6 days (up to $18 \mathrm{~d}$ post mortem) in comparison with air-packed samples. Taxifolin treatment of air-packaged beef was not effective for shelf-life extension. The combined application of taxifolin treatment and modified atmosphere packaging improved quality and extend shelf-life of chilled beef.
\end{abstract}

Keywords: beef, natural antioxidant, modified atmosphere, lipolysis, shelf-life

\section{INTRODUCTION}

Extension of the quality and shelf-life of packed chilled beef was one of the technology necessities to meet the demands of consumers. In this respect, increasing attention was put on modified atmosphere packaging (MAP) (Narasimha Rao and Sachindra, 2002).

The preserved effect of beef MAP packaging has been strengthened by spraying with natural antioxidants such as: carnosine, carnetine and Lascorbic acid solutions (Djenane et al., 2004); combination between pulverization with rosemary and vitamin $\mathrm{C}$ and MAP $\left(70 \% \mathrm{O}_{2} / 20 \% \mathrm{CO}_{2} / 10 \% \mathrm{~N}_{2}\right)$ (Djenane et al. 2003); combined effect of rosemary extract and ascorbate/citrate $/ 1: 1 /$ and MAP $\left(100 \% \mathrm{~N}_{2}\right.$ or $80 \% \mathrm{O}_{2} / 20 \% \mathrm{~N}_{2}$ ) (Lund et al. 2007).

The application of bioflavonoides as natural antioxidants for treatment of fresh MAP meat has not been discussed in the available literature. Depending on the presence or absence of double bond in the heterocyclic ring bioflavonoides were classified as favons and flavonons (Harada et al., 1992). One well known representative of the flavones is quercetin (Mitchell et al., 2007). The dihydroquercetin (known also as taxifolin) is a member of the group of flavonons (Vladimirov et al., 2009).
The satisfactorily pure taxifolin may be extracted from Siberian larch (Larix sibirica Ledeb). There are evidences that this type of taxifolin is efficient antioxidant for edible oils (Poltnikov et al., 2000), lard (Tiukavkina et al., 1997), poultry fats (Krasiukov et al., 2006), dry milk powder (Rulenko et al., 1995), rich of fats sweets (Plotnikov et al., 1993), groun meat (Gurinovitch et al., 2006), and chilled salmon (Ivanov et al. 2009; Balev et al. 2009).

The analysis of the available literature showed that the combination of taxifolin treatment and MAP for inhibition of oxidative processes in beef has not been performed.

The objective of the present study was to establish the possibilities for improving the quality and for prolonging the shelf-life of beef cuts by using a combination of MAP $\left(80 \% \mathrm{O}_{2} / 20 \% \mathrm{CO}_{2}\right)$ and superficial taxifolin treatment.

\section{MATERIALS AND METHODS}

Materials: The beef was supplied by the company "Unitemp" Ltd, Voyvodinovo village, district Plovdiv, Bulgaria. The carcase quarters LOT: L0801300201 were imported from Poland. The carcrases were boned and sorted.

Taxifolin (2R, 3R-dihydroquercetin) solution preparation. Powder concentrate of taxifolin (Figure 
2), extracted from Siberian larch (Larix sibirica Ledeb) and produced by the company Flavit Ltd, Pushtino (Russia) was used. The concentrate contained: $\quad 96 \%$ dihydroquercetin, $3 \%$ dihydrokempferol and traces of naringenin. One $\mathrm{g}$ taxifolin was diluted in $50 \mathrm{~cm}^{3} 96 \%$ ethyl alcohol and filled up to $1 \mathrm{dm}^{3}$ with $950 \mathrm{~cm}^{3}$ double distillated water. For treatment of fifty $\mathrm{kg}$ beef, $1 \mathrm{dm}^{3}$ of the solution was used.

Modified atmosphere. Some samples of beef cuts were packaged in a modified atmosphere consisting of $80 \% \mathrm{O}_{2} / 20 \% \mathrm{CO}_{2} \quad$ (MAP), according recommendations of Manchini and Hunt (2005).

Experimental design: The beef cuts were packed at the $6 \mathrm{~d}$ post mortem. The experiments were performed by using the fallowing samples: control $C_{A}$ - air-packaged and not treated with taxifolin beef trimmings 90/10\%; sample $\mathrm{MA}_{A}-\mathrm{MOP}$ and not treated with taxifolin beef trimmings $90 / 10 \%$; sample $\mathrm{T}_{\mathrm{A}}$ - air-packaged and treated with taxifolin beef trimmings $90 / 10 \%$; sample $\mathrm{TMA}_{A}-\mathrm{MOP}$ and treated with taxifolin beef trimmings $90 / 10 \%$; control $C_{B}$ - airpackaged and not treated with a taxifolin beef knuckles with bone; sample $M_{B}-$ MOP and not treated with taxifolin beef knuckles with bone; sample $\mathrm{T}_{\mathrm{B}}$ - air-packaged and treated with taxifolin beef knuckles with bone; $\mathrm{TMA}_{B}$ - MOP and treated with taxifolin beef knuckles with bone.

The samples were strained off for $60 \mathrm{~min}$ at $1.2^{\circ} \mathrm{C}$. The temperature of air in the premises for packaging was $7.5^{\circ} \mathrm{C}$. Samples were stored at $0 \pm 0.5^{\circ} \mathrm{C}$ before analysis. The analyses were carried out on $6 \mathrm{~d}$ post mortem ( $1^{\text {st }} \mathrm{d}$ of the experiment); $9 \mathrm{~d}$ post mortem ( $3^{\text {rd }}$ $\mathrm{d}$ of the experiment - after three days of refrigeration storage), $12 \mathrm{~d}$ post mortem ( $6^{\text {th }} \mathrm{d}$ of the experiment after six days of refrigeration storage), and $18 \mathrm{~d}$ post mortem $\left(12^{\text {th }}\right.$ of the experiment - after twelve days of refrigeration storage).

The beef proximate composition determination was performed by analyzing the beef trimmings, obtained from different parts of carcasses and beef knuckles. The samples were analyzed after $12^{\text {th }} \mathrm{d}$ of refrigeration storage at $0^{\circ} \mathrm{C}(18 \mathrm{~d}$ post mortem $)$. The average laboratorial samples were prepared and five repetitions were done.

\section{Methods:}

Sample preparation: The samples were obtained according ISO 3100-1:1991. Before analysis samples were stored at $0^{\circ} \mathrm{C}$ for no more than $6 \mathrm{~h}$.

Analysis of the proximate composition of beef: The moisture content was determined by drying at $105^{\circ} \mathrm{C}$ (Kirkbright et al., 2007). The ash content of the samples was determined after drying at $102^{\circ} \mathrm{C}$ and heating in a muffle oven at $525^{\circ} \mathrm{C}$ for $4 \mathrm{~h}$ (Perez and Andujar, 1980). Crude proteins were analyzed according to the Kjeldahl method by using of an automatic analyzer Keltec Auto, model 1030 (Tecator, Sweden). The proteins were calculated by using of a conversion factor 6.25 (King and Sebranek, 1993). The total lipids determination was performed by diethyl ether extraction in Soxhlet extractor (Jensen, 2007).

Determination of amine nitrogen: Amine nitrogen content of studied samples was determined by the Sørensen method (Sundaran et al. 2001) modified to suit the specific conditions of the analysis.

Lipid extraction and determination of acid value : Lipids were extracted according to Bligh and Dyer (1959) method. Acid value (AV) of the extracted lipids was determined according EVS-EN ISO 660:2009 (Kardash and Tur'yan, 2005).

Microbiological analysis: The bacteriological tests were carried out in accordance with microbiological criteria of Commission Regulation (EC) No 1441/2007. The microbiological analysis were performed as follow: Listeria monosytogenes according ISO 11290-2002 (Scotter et al., 2001); Salmonella spp. according ISO 6579-2002 (Piknová et al., 2002); Escherichia coli according ISO 166491:2001 (Nastasijevic et al., 2009); total aerobic colony count according EN ISO/DIS 4833-2001 (Cohen et al., 2007).

Statistical analysis: Data were statistically analyzed by using of the SPSS 11.0 software (SPSS Inc., Chicago, Illinois, USA). Nine repetitions $(n=9)$ for each sample were carried out. Data were analyzed by the analysis of variance (one-way ANOVA) method with a significant level of $P \leq 0.05$ (Draper and Smith, 1998). The Duncan's multiple comparison test (SPSS) with a significant difference set at $P \leq 0.05$ was used to compare sample means. Significant differences between means less than 0.05 were considered statistically significant (Kenward, 1987).

\section{RESULTS AND DISCUSSIONS}

Beef Proximate Composition: The results obtained showed that the taxifolin treatment and MAP did not modify significantly the proximate composition of beef (Figure 1 and Figure 2). The proximate composition of the experimental samples was typical for beef cuts at $18 \mathrm{~d}$ post mortem $\left(12^{\text {th }} \mathrm{d}\right.$ of the refrigeration storage). 
Sample A - beef trimmings 90/10\%

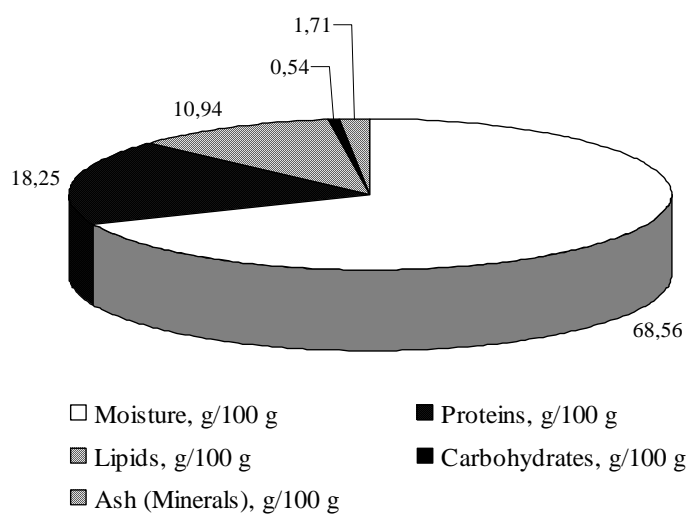

Fig 1. Proximate composition of samples A - beef trimmings $90 / 10 \%$

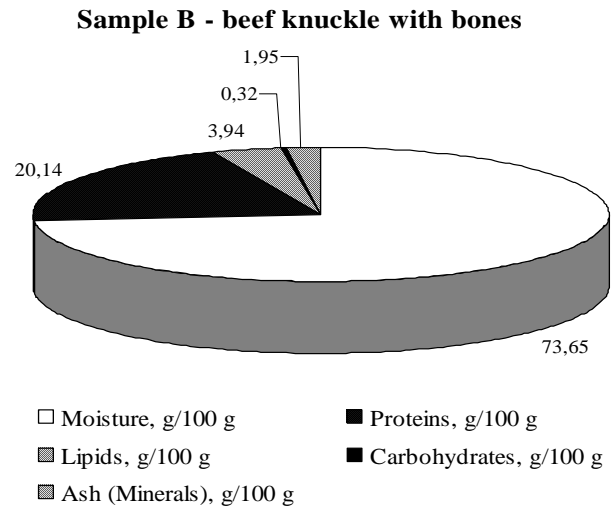

Fig 2. Proximate composition of samples B - beef knuckles with bones

It is well known that the lipid content of beef is very variable parameter. It depends from anatomical and topographical muscle location, muscle type, species, sex, ages and the manner of nutrition and breeding. Therefore, 10 - $11 \mathrm{~g}$ lipids $/ 100 \mathrm{~g}$ beef trimmings and 3 - $4 \mathrm{~g}$ lipids/100 $\mathrm{g}$ beef knuckles were considered to be typical.

The ash content of the beef cuts, representing its total mineral content, varied from 1.71 to $1.95 \mathrm{~g} / 100 \mathrm{~g}$ beef, which values are also typical for beef.

Amino Nitrogen Content: Amino nitrogen content of all studied samples increased significantly $(P<0.05)$ during refrigerated storage at $0 \pm 0.5{ }^{\circ} \mathrm{C}$ (Figure 3). After 12 days of child storage, the amino nitrogen content of control samples $C_{A}$ and $C_{B}$ increased from $0,45 \mathrm{mg} / 100 \mathrm{~g}$ to $5,91 \mathrm{mg} / 100 \mathrm{~g}$ and from 0,51 $\mathrm{mg} / 100 \mathrm{~g}$ to $6,57 \mathrm{mg} / 100 \mathrm{~g}$, respectively. The results obtained showed, that the superficial treatment with taxifolin solution $\left(1 \mathrm{~g} / \mathrm{dm}^{3}\right)$ and MAP delayed to the certain extend the amino nitrogen accumulation. The lowest levels of amino nitrogen content were determined in MAP samples $\left(M_{A}\right.$ and $\left.M A_{B}\right)$, fallowed by MOP and treated with taxifolin samples $\left(T_{M A}\right.$ and $\left.T_{M} A_{B}\right)$. Air-packed and treated with taxifolin samples $\left(T_{A}\right.$ and $T_{B}$ ) had a little bit lower amino nitrogen concentrations than the control samples. These results showed that the application of MOP had greater effect on inhibition of proteolysis in beef than taxifolin treatment.

The more intensive proteolysis in air-packed samples $\left(C_{A}, C_{B}, T_{A}\right.$, and $\left.T_{B}\right)$ may be explained with the accelerated growth of aerobic bacteria in beef (Edwards et al., 1987; Abd El-Rhman et al., 1998). The main factor for MAP beef spoilage is the activity of lactic acid bacteria (Doulgeraki et al., 2009).

Free Fatty Acids Accumulation: The accumulation of free fatty acids in beef was established by monitoring the changes in acid value (AV) of the studied samples. It was found, that the AV of all samples increased significantly $(P<0.05)$ during the child storage (Figure 4). It is well known, that the free fatty acid accumulation in meat is a consequence of hydrolytic changes in muscle lipids and adipose tissue located around the muscles (Gandemer, 1990). Therefore, the results obtained (Figure 4) indicated for lipid hydrolysis development during storage of the studied samples. At the $18 \mathrm{~d}$ post mortem AV of beef trimmings increased by approximately $88 \%, 65 \%$ and $62 \%$ for $\mathrm{MA}_{\mathrm{A}}, \mathrm{T}_{\mathrm{A}}$ and $\mathrm{TMA}_{\mathrm{A}}$ samples, respectively. Similar changes in AV during child storage of the beef knuckles were established. At the $18 \mathrm{~d}$ post mortem AV of beef knuckles increased by approximately $94 \%, 78 \%$ and $71 \%$ for $\mathrm{MA}_{\mathrm{B}}, \mathrm{T}_{\mathrm{B}}$ and $\mathrm{TMA}_{\mathrm{B}}$ samples, respectively.

It is evident, that taxifolin treatment had greater effect on inhibition of lipolysis development in beef than MOP. Such effect could be explained by the inhibitory activity of taxifolin toward muscle lipases and phospholipases (Tiukavkina et al., 1997). It was found that, the superficial spraying of beef trimmings with taxifolin solution $\left(1 \mathrm{~g} / \mathrm{dm}^{3}\right)$, individually or in a combination with MAP $\left(80 \% \mathrm{O}_{2} ; 20 \% \mathrm{CO}_{2}\right)$ delayed the free fatty acids accumulation during child storage with $10 \%$ to $12 \%$ in comparison with the control samples. Such treatment is less effective for inhibition of lipolysis in beef knuckles, which is demonstrated by the greater increase of $\mathrm{AV}$ during child storage of $\mathrm{MA}_{\mathrm{B}}, \mathrm{T}_{\mathrm{B}}$ and $\mathrm{TMA}_{\mathrm{B}}$ samples. However, the levels of $\mathrm{AV}$ determined at the end of 
the experiment, indicated for initial stage of lipolysis development in all studied samples.

Microbiological characteristics: The results from microbiological analysis (Table 1) showed that $\mathrm{TMA}_{\mathrm{A}}$, $T_{M A}, M A_{A}$ and $M A_{B}$ samples preserved their microbiological quality during the whole $12 \mathrm{~d}$ period of refrigeration storage at $0 \pm 0.5{ }^{\circ} \mathrm{C}$. The microbiological characteristics of these samples remained in the standard norms for freshness and hygiene of beef (ISO 2073). In contrast to them, according to the microbiological tests the samples $T_{A}$ and $T_{B}$ could be considered as safety up to $6 \mathrm{~d}$, and control samples $C_{A}$ and $C_{B}-$ up to $3 d$ of refrigeration storage. The results reported by us were in agreement with the findings of Barbary and Zeitoun (1992).

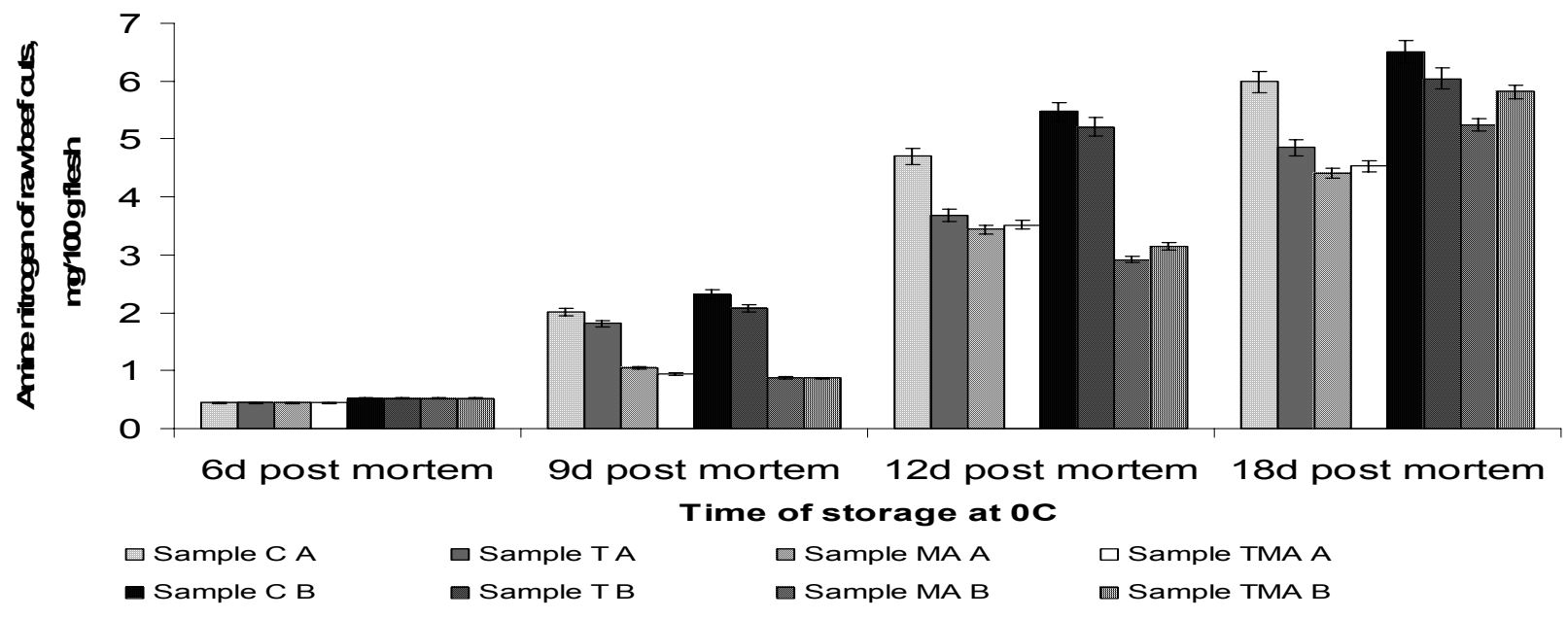

Fig 3. Accumulation of the products of enzymatic catalyzed protein hydrolysis during 8 days refrigeration storage at $0^{\circ} \mathrm{C}$ of samples $A$ - beef trimmings $90 / 10 \%$ and samples $B$ - beef knuckle with bones, expressed by changes of amine nitrogen

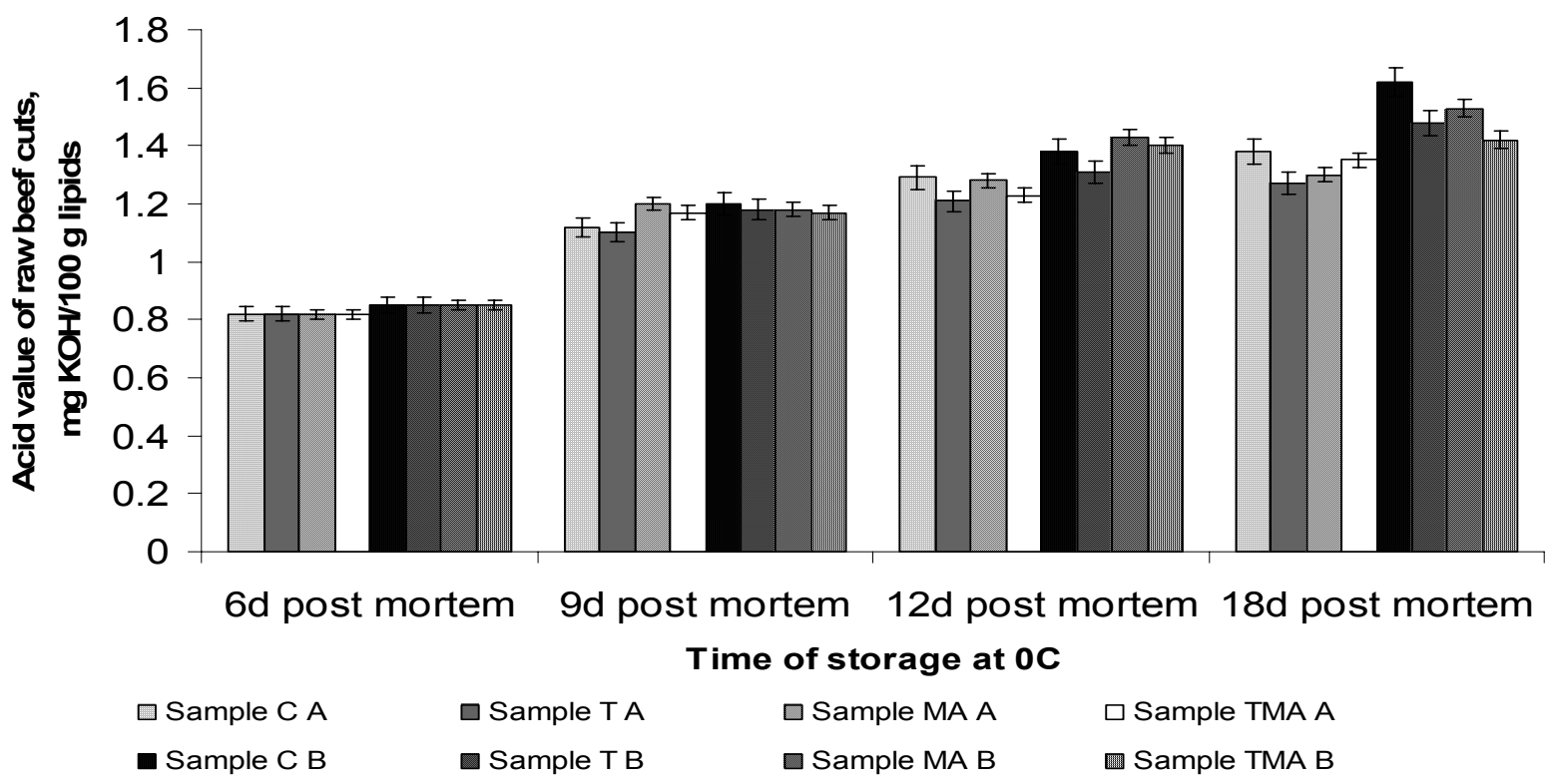

Fig 4. Hydrolitical changes of total lipids during 8 days refrigeration storage at $0^{\circ} \mathrm{C}$ of samples $\mathrm{A}$ - beef trimmings $90 / 10 \%$ and samples $B$ - beef knuckle with bones, expressed by changes of acid value 
Agric. Biol. J. N. Am., 2010, 1(4): 451-457

Table 1. Mean $\pm S$.D. (log CFU/g) for aerobic plate counts (APC), E. coli counts (ECC), and the incidence of $L$. monocytogenes and Salmonella spp. for studied beef samples

\begin{tabular}{|c|c|c|c|c|c|}
\hline Samples & $\begin{array}{l}\text { Period of } \\
\text { storage. d }\end{array}$ & APC & ECC & L. monocytogenes & Salmonella spp. \\
\hline \multicolumn{6}{|c|}{ Beef trimmings $90 / 10 \%$} \\
\hline & 1 & $2.6 \pm 0.9$ & $1.2 \pm 0.5$ & ND & ND \\
\hline \multirow{4}{*}{ Sample $C_{A}$} & 3 & $4.4 \pm 1.6$ & $2.0 \pm 0.4$ & 1 & ND \\
\hline & 6 & $6.2 \pm 1.4$ & $2.9 \pm 0.4$ & 3 & ND \\
\hline & 12 & $7.5 \pm 1.1$ & $3.4 \pm 0.6$ & 5 & 1 \\
\hline & 1 & $2.4 \pm 1.4$ & $1.3 \pm 0.4$ & ND & ND \\
\hline \multirow[t]{4}{*}{ Sample $T_{A}$} & 3 & $3.4 \pm 0.8$ & $1.8 \pm 0.5$ & ND & ND \\
\hline & 6 & $4.1 \pm 1.2$ & $2.1 \pm 0.3$ & 2 & ND \\
\hline & 12 & $6.5 \pm 1.1$ & $3.6 \pm 0.7$ & 5 & 1 \\
\hline & 1 & $2.2 \pm 0.9$ & $1.3 \pm 0.5$ & ND & ND \\
\hline Sample & 3 & $2.4 \pm 1.6$ & $1.3 \pm 0.5$ & ND & ND \\
\hline \multirow[t]{3}{*}{$\mathbf{M A}_{\mathbf{A}}$} & 6 & $2.6 \pm 1.4$ & $1.5 \pm 0.6$ & ND & ND \\
\hline & 12 & $3.5 \pm 1.1$ & $2.0 \pm 0.4$ & ND & ND \\
\hline & 1 & $2.3 \pm 0.9$ & $1.2 \pm 0.5$ & ND & ND \\
\hline \multirow{3}{*}{$\begin{array}{c}\text { Sample } \\
\text { TMA }_{A}\end{array}$} & 3 & $2.4 \pm 1.4$ & $1.3 \pm 0.7$ & ND & ND \\
\hline & 6 & $2.9 \pm 1.1$ & $1.6 \pm 0.3$ & ND & ND \\
\hline & 12 & $3.1 \pm 1.1$ & $1.8 \pm 0.4$ & ND & ND \\
\hline \multicolumn{6}{|c|}{ Beef knuckles with bones } \\
\hline \multirow{5}{*}{ Sample $C_{B}$} & 1 & $2.9 \pm 0.9$ & $1.1 \pm 0.4$ & ND & ND \\
\hline & 3 & $4.9 \pm 1.6$ & $2.2 \pm 0.6$ & 2 & ND \\
\hline & 6 & $6.8 \pm 1.4$ & $3.1 \pm 0.5$ & 4 & ND \\
\hline & 12 & $7.8 \pm 1.1$ & $4.0 \pm 0.5$ & 5 & 2 \\
\hline & 1 & $3.1 \pm 1.4$ & $1.4 \pm 0.3$ & ND & ND \\
\hline Sample & 3 & $3.7 \pm 0.8$ & $2.0 \pm 0.5$ & ND & ND \\
\hline \multirow[t]{3}{*}{$\mathbf{T}_{\mathrm{B}}$} & 6 & $4.4 \pm 1.2$ & $2.2 \pm 0.7$ & 3 & ND \\
\hline & 12 & $6.4 \pm 1.1$ & $3.8 \pm 0.7$ & 5 & ND \\
\hline & 1 & $3.2 \pm 0.9$ & $1.2 \pm 0.5$ & ND & 1 \\
\hline \multirow{4}{*}{$\underset{M_{B}}{\text { Sample }}$} & 3 & $3.2 \pm 1.6$ & $1.4 \pm 0.7$ & ND & ND \\
\hline & 6 & $3.6 \pm 1.4$ & $1.4 \pm 0.5$ & ND & ND \\
\hline & 12 & $4.1 \pm 1.1$ & $2.0 \pm 0.6$ & ND & ND \\
\hline & 1 & $3.1 \pm 0.9$ & $1.4 \pm 0.5$ & ND & ND \\
\hline \multirow{3}{*}{$\begin{array}{l}\text { Sample } \\
\text { TMA }_{B}\end{array}$} & 3 & $3.4 \pm 1.4$ & $1.5 \pm 0.5$ & ND & ND \\
\hline & 6 & $3.9 \pm 1.1$ & $1.6 \pm 0.4$ & ND & ND \\
\hline & 12 & $4.1 \pm 1.1$ & $1.9 \pm 0.4$ & ND & ND \\
\hline
\end{tabular}

\section{CONCLUSIONS:}

The results obtained showed that the packaging of beef in modified atmosphere $80 \% \mathrm{O}_{2} / 20 \% \mathrm{CO}_{2}$, combined with preliminary superficial treatment of the meat with taxifolin solution $(1 \mathrm{~g} / \mathrm{L})$ improved the quality of chilled beef and extended the shelf-life up to $18 \mathrm{~d}$ post mortem $\left(12 \mathrm{~d}\right.$ of storage at $0 \pm 0.5^{\circ} \mathrm{C}$ ). This shelf-life of TMA beef was with 6 days longer in comparison with air-packed samples. Taxifolin treatment of air-packed beef was not effective for shelf-life extension.

ACKNOWLEDGEMENTS:
The author expresses his gratitude to the technological team of the company Unitemp Ltd, Voyvodinovo, Plovdiv region, as well as the management of the company Vita-life Ltd, Sofia for the co-operation and support rendered.

\section{REFERENCES}

Abd El-Rhman, H.A., Marriott, N.G., Wang, H., Yasssein, M.M.A. and Ahmed, A.M. (1998). Characteristics of minced beef stored at chilled and abuse temperatures, Journal of Muscle Foods 9: 139-152.

Balev, D., Ivanov, G., Nikolov, H. and Dragoev, S. (2009). Effect of pre-treatment with natural antioxidants on the 
color surface properties of chilled stored salmon discs. Bulg. J. Agric. Sci., 15: 379-385.

Barbary, O.M. and Zeitoun, M.M. (1992). Effect of modified atmosphere packaging on sensory evaluation, microbiological and lipid oxidation quality of processing meat during cold storage, Mansoura Journal of Agricultural Science 17: 1080-1091.

Bligh, E.G. and Dyer W.J. (1959). A rapid method of total lipid extraction and purification, Canadian Journal of Biochemistry and Physiology 37: 911-917.

Cohen, N., Ennaji, H., Bouchrif, B., Hassar, M. and Karib, $\mathrm{H}$. (2007). Comparative study of microbiological quality of raw poultry meat at various seasons and for different slaughtering processes in Casablanca (Morocco), Journal of Applied Poultry Research 16: 502-508.

Djenane, D., Escalante, A. and Roncales, P. (2003). Extension of the shelf life of beef steaks packaged in a MAP by treatment with rosemary and display under UV-free lighting, Meat Science 65: 417- 426.

Djenane, D., Martinez, L., Sanches-Escalante, A., Beltran, J.A. and Roncales, P. (2004). Antioxidant effect of carnosine and carnitine in fresh beef steaks stored under modified atmosphere, Food Chemistry 85: 453459 .

Doulgeraki, A., Nisiotou, A. and Nychas, G.-J. (2009). Contribution of lactic acid bacteria population in meat stored under modified atmospheres. In: Duffy, G. and Nychas G.-J. (eds), Proc. of a Meeting at Ashtown Food Research Conference Centre "Advancing Beef safety through Research and Innovation", March 2526, 2009 Teagasc, Dublin, Ireland Dublin: Teagasc Ashtown Food Research Centre CRC. pp. 88.

Draper, N.R. and Smith, H. (1998). Applied Regression Analysis, $3^{\text {-rd }}$ edn., New York: Wiley. pp. 124-148.

Edwards, R.A., Dainty, R.H., Hibbard, C.M. and Ramantanis, S.V. (1987). Amines in fresh beef of normal $\mathrm{pH}$ and the role of bacteria in changes in concentration observed during storage in vacuum packs at chill temperature, Journal of Applied Microbiology 63: 427-434.

Gandemer, G. (1990). Les phospholipids du muscle: composition et alteration an cours des treatments technologiques, Revue Francaise des Corps Gras 37: 75 - 81. [In Frances]

Gurinovitch, G.V., Lisin, K.V. and Potipaeva, N.N. (2006). Preparation for extension of meat semi manufactured articles, Meat Industry 3: 31-33 [In Russian].

Harada, N., Ono, H., Uda, H., Parveen, M., Din, Kh.N., Achari, B., Dutta, Pr.K. (1992). Atropisomerism in natural products. Absolute stereochemistry of biflavone, (-)-4',4"',7,7"-tetra-O-methylcupressuflavone, as determined by the theoretical calculation of
CD spectra, Journal of American Chemist's Society 114: 7687-7692.

Ivanov, G., Balev, D., Nikolov, H. and Dragoev, S. (2009). Improvement of the chilled salmon sensory quality by pulverization with natural dihydroquercetin solutions. Bulg. J. Agric. Sci., 15: 154-162.

Jensen, W.B. (2007). The Origin of the Soxhlet Extractor, Journal of Chemical Education 84: 1913-1917.

Kardash, E. and Tur'yan, Y.I. (2005). Acid value determination in vegetable oils by indirect titration in aqueous-alcohol media, Croatica Chemica Acta 78: 99-103.

Kenward, M.G. (1987). A method for comparing profiles of repeated manuscripts, Applied Statistics 36: 296 308.

King, B.M. and Sebranek, J.G. (1993). Combustion method for determination of crude protein in meat and meat products: collaborative study, Journal of AOAC International 76: 787-793.

Kirkbright, G.F., Mayne, P.J. and West, T.S. (2007). Technical note: Application of a permittivity method for the rapid determination of water in meat, International, Journal of Food Science \& Technology 10: 103-108.

Krasiukov, U.N., Gonotzkii, V.A., Dubrovskaia, F.I. and Fedina, L.P. (2006). Dihydroquercetin - hopeful stabilizer of the quality of poultry fat, Birds and Poultry Products 4: 54-58 [In Russian].

Lund, M.N., Hviid, M.S. and Skibsted, L.H. (2007). The combined effect of antioxidants and modified atmosphere packaging on protein and lipid oxidation in beef patties during chill storage, Meat Science 76 : 226-233.

Mancini, R.A. and Hunt M.C. (2005). Current Research in Meat Colour, Meat Sci. 71: 100 - 121.

Meat Science 82: 101-105

Mitchell, A.E., Hong, Y.J., Koh, E., Barrett, D.M., Bryant, D.E., Denison, R.F. and Kaffka, S. (2007). Ten-year comparison of the influence of organic and conventional crop management practices on the content of flavonoids in tomatoes, J. Agric. Food Chem. 55: 6154-6159.

Narasimha Rao, D. and Sachindra, N.M. (2002). Modified atmosphere and vacuum packaging of meat and poultry products, Food Rev. Int. 18: 263-293.

Nastasijevic, I., Mitrovic, R. and Buncic, S. (2009). The occurrence of Escherichia coli 0157 in/on faeces, carcasses and fresh meats from cattle, Perez, D. and Andujar, G. (1980). Determination of ash content in meat products, Meat Science 5: 165-170.

Piknová, L., Štefanovicová, A., Drahovská, H., Sásik, M. and Kuchta, T. (2002). Detection of Salmonella in food, 
equivalent to ISO 6579 , by a three-days polymerase chain reaction-based method, Food Control 13: 191194.

Plotnikov, M.B., Kolesnik, U.A., Tiukavkina, N.A., Ostrouhova, L.A., Daurskii, A.N., Kondakova, I.A., Smirnova, N.I., Tesselkin, N.A., Babenkova, I.V. and Klebanov, G.I. (1993). Confectionary with addition of the biologically active substances. 2 . Antioxidant action of dihydroquercetin in the composition of confectionary base on fat, Biotechnology and Management 3-4: 2730 [In Russian].

Plotnikov, M.B., Maslov, M.U., Aliev, O.I., Vassilev, A.S., Plotnikova, T.M., Tiukavkina, N.A., Kolesnik, U.A. and Savateev, A.M. (2000). Development of a new biological active additive for food "Antoxid". In: Tiukavkina N.A. (ed), Pros. IV International Conference Actual Problems for Development of New Drugs with Natural Origin, 3 -5 July 2000, Great Novgorod, Russia: Great Novgorod Press. pp. 210-216 [In Russian].

Rulenko, I.A., Tiukavkina, N.A., Radaeva, I.A., Kolesnik, U.A., Plotnikov, M.B., Maslov, M.U., Plotnikova, T.M., and Savateev, A.M. (1995). Analysis of dihydroquercetin in dry milk powder products by the method of HPLC, Questions of Nutrition 3: 28-30 [In Russian].

Scotter, S.L., Langton, S., Lombard, B., Schulten, S., Nagelkerke, N., In't Veld, P.H., Rollier, P. and Lahellec, C. (2001). Validation of ISO method 11290 part 1detection of Listeria monocytogenes in foods, International Journal of Food Microbiology 64: 295306.

Tiukavkina, N.A., Rulenko, I.A. and Kolesnik, U.A. (1997). Dihydroquercetin - a new antioxidant and biological active food additive, Questions of Nutrition 6: 5-12 [In Russian].

Vladimirov, Yu.A., Proskurnina, E.V., Demin, E.M., Matveeva, N.S., Lubitskiy, O.B., Novikov, A.A., Izmailov, D.Yu., Osipov, A.N., Tikhonov, V.P. and Kagan, V.E. (2009). Dihydroquercetin (Taxifolin) and other flavonoids as inhibitors of free radical formation at key stages of apoptosis, Biochimia 74: 372-379. 